\title{
Flavour development via lipolysis of milkfats: changes in free fatty acid pool
}

\author{
Mafalda A. Regado, ${ }^{1}$ Betina M. Cristóvão, ${ }^{1}$ Carla G. Moutinho, ${ }^{2}$ Victor M. Balcão, ${ }^{2}$ Raquel Aires-Barros, ${ }^{3}$ \\ João Paulo M. Ferreira' ${ }^{1}$ \& F. Xavier Malcata ${ }^{1 *}$ \\ 1 Escola Superior de Biotecnologia, Universidade Católica Portuguesa, Rua Dr. António Bernardino de Almeida, P-4200-072 Porto, Portugal \\ 2 Centro de Bioengenharia e FármacoClínica, Universidade Fernando Pessoa, Praça 9 de Abril, P-4249-004 Porto, Portugal \\ 3 Centro de Engenharia Biológica e Química, Instituto Superior Técnico, Avenida Rovisco Pais, P-1049-001 Lisboa, Portugal
}

Summary Under the trade name lipolysed milkfat (LMF), concentrated cheese flavours obtained via enzymatic treatments of cheese (or other dairy substrates) have been made available in increasing numbers. In this research effort, (anhydrous) milkfats from cows, ewes and goats were used as substrates for production of cheesy flavours. Those milkfats were subjected to modifications brought about by ten different (commercial) lipases and one cutinase, and the free fatty acids released were analysed by high performance liquid chromatography. Both the degrees of hydrolysis and the free fatty acid profiles of the final products were similar to those reported for several LMF products, although specific keynotes could be pinpointed. Consequently, those milkfats may represent alternative raw materials for manufacture of cheesy flavours, while contributing to alleviate the problem derived from the increasing surplus of milkfat in Western countries.

Keywords Chemical or enzymatic modifications, dairy products, enzymes-food processing aspects, fatty acids, lipolysis, milk/milk products.

\section{Introduction}

Partial hydrolysis of fat in milk is typically an enzymemediated transformation that is intrinsic to several dairy products. Such a process can be carried out: by the enzymes released by native microflora (when viable or upon lysis), as occurs in raw milk cheese manufacturing; or by deliberately added extraneous enzymes. Depending on the extent and specificity of said hydrolysis, enzymatically modified milkfat will exhibit distinct flavour notes: at very low extent, lipolysis can impart sensory tones of acid-free richness; at relatively higher extent, the modified fat acquires either a buttery, a creamy or a cheesy taste.

Lipolysed milkfat (LMF) has accordingly become an important ingredient in the food industry. There are several current and potential applications thereof, such as an additive to bakery products (bread, cake and cookie mixes), cereal products (flakes), candies (chocolate products and toffees), dairy products (coffee whiteners, confectionary creams, cheese and butter spreads) and a variety of other products (popcorn seasoning, sauces, salad dressings and snack foods). Under specific

*Correspondent: Fax: + 351225090351 ;

e-mail: fxmalcata@esb.ucp.pt processing conditions, LMF may actually exhibit an intense cheese flavour - in this case, it is often used in enzyme-modified cheeses (EMC). LMFs may thus be viewed as a vehicle of cheese flavours, produced by enzymatic modification of dairy substrates, viz. milkfat. Besides being inexpensive in manufacture, they are easy to store, have long shelf-lives and are consistent from batch-to-batch (Kilcawley, 2001). Therefore, they are convenient ingredients for many processed foods - e.g. sauces, salad dressings, pasta and pizza products, cheese-spreads, frozen and canned foods, and biscuits, as they impart intense flavour even at low incorporation rates [typically below $2 \%(\mathrm{w} / \mathrm{w})$ ].

In the manufacture of LMF specifically from cheese curd, the substrate is mixed with emulsifying salts, and both proteolytic and lipolytic enzymes may be added; this slurry is then kept at an optimal temperature for a certain period of time (Talbott \& McCord, 1981). During incubation, protein is hydrolysed by proteases into peptides and free amino acids, hence decreasing viscosity. Simultaneously, lipases catalyse the partial and selective hydrolysis of fat into a mixture of free fatty acids, hence generating flavour compounds or precursors thereof. Among these, short-chain fatty acids play a nuclear role in imparting the cheesy taste (Ha \& Lindsay, 1993; Lai et al., 1997). Long-chain fatty acids 
are also important, but their concentration should not exceed a given threshold so as to avoid soapy tastes. The ratio of short-to-long chain fatty acids in free form is thus an important parameter, which depends to a great extent on the enzyme(s) utilised. Lipases employed in LMF manufacture may be from animal or microbial origins; the choice of these enzymes is critical, as it dictates the final profile of the fatty acids released, and consequently the flavour of the resulting product.

In this research effort, ten lipases and one cutinase an enzyme able to hydrolyse ester bonds in the absence of an interface - were employed to bring about (partial) lipolysis of bovine, caprine and ovine milkfats. Fatty acids released into the reaction media were analysed by high performance liquid chromatography, and the profiles obtained were duly compared with each other and discussed.

\section{Experimental}

\section{Materials}

Enzymes

The lipases utilised were commercial (crude) preparations kindly supplied by Amano Pharmaceutical (Nagoya, Japan), obtained from Candida cylindracea $\left(\mathrm{AY} 30^{\mathrm{TM}}\right)$, Candida lipolytica $\left(\mathrm{L}^{\mathrm{TM}}\right)$, Rhizopus delemar $\left(\mathrm{D} 20^{\mathrm{TM}}\right)$, Rhizopus niveus $\left(\mathrm{N}^{\mathrm{TM}}\right)$, Penicillium roquefortii $\left(\mathrm{R} 10^{\mathrm{TM}}\right)$, Penicillium camembertii $\left(\mathrm{G} 50^{\mathrm{TM}}\right)$, Pseudomonas fluorescens (AK20 $\left.{ }^{\mathrm{TM}}\right)$, Humicola lanuginosa $\left(\mathrm{CE} 10^{\mathrm{TM}}\right)$, Geotrichum candidum (GC4) and Mucor circinelloides (M10). The cutinase utilised was a (crude) laboratory preparation from Fusarium solani-pisi, obtained from a recombinant Saccharomyces cerevisiae strain (SU50) (Calado et al., 2002).

\section{Processing apparatus}

A 200-mL-volume, round bottom flask, inserted within a jacketed glass beaker (Schott, Mainz, Germany), was used to carry out each of the hydrolysis reactions. The supporting setup comprised a constant temperature bath equipped with a mechanical agitator and a digital temperature controller (Julabo Labortechnik GMBH, Seelbach, Germany), with external recirculation through the jacketed glass beaker.

\section{Chemicals}

Orthophosphoric acid $(85 \%, \mathrm{v} / \mathrm{v})$, potassium carbonate, sodium hydroxide and anhydrous sodium sulphate were obtained from Merck (Darmstadt, Germany); 18crown-6-ether was purchased from Merck (München, Germany); butylated hydroxyanisole, $p$-bromophenacylbromide, polyethylene glycol (PEG) 3350 and potassium phosphate were from Sigma (St Louis MO, USA); chloroform, formic acid, acetonitrile $\left(190^{\mathrm{TM}}\right)$ and methanol $\left(205^{\mathrm{TM}}\right)$ were from ROMIL Chemicals (Leicester,
UK). All free fatty acid standards ( $>99.9 \%$ pure) were obtained from Sigma. Fermentation ethanol [96\% (v/v)] was obtained from AGA (Lisbon, Portugal). Dry nitrogen $\left(\mathrm{C}-55^{\mathrm{TM}}\right)\left(<1\right.$ parts per million $\mathrm{H}_{2} \mathrm{O}$ and $<1 \mathrm{vpm} \mathrm{O}_{2}$ ) was purchased from Carburos Metalicos (Barcelona, Spain). All chemicals purchased were reagent-grade or higher, and were used without further purification. Water was subjected to sequential steps of reverse osmosis, adsorption, deionisation, microfiltration and photo-oxidation in a Milli-Q Plus 185 water purification system (Molsheim, France), to a final conductivity of $18.2 \mathrm{M} \Omega \mathrm{cm}^{-1}$.

\section{Substrates}

Salt-free, pasteurised butter produced from bovine milk was purchased from AGROS (Vila do Conde, Portugal), and kept at $-30{ }^{\circ} \mathrm{C}$ in sealed plastic bags of c. $250 \mathrm{~g}$ until experimental use. Butters (unsalted) produced from ovine and caprine milks were kindly supplied by ANCOSE (Guarda, Portugal), and also stored in sealed plastic bags at $-30{ }^{\circ} \mathrm{C}$ prior to use.

\section{Analytical equipments}

Nylon membrane filters (NALGENE ${ }^{\mathrm{TM}}, 0.45 \mu \mathrm{m}$ ) were purchased from Nalge (New York, NY, USA). The HPLC equipment (MERCK, Darmstadt, Germany) consisted of a programmable autosampler (model L7250), a LichroCART ${ }^{\circledR} 250-4$ C-18 reversed-phase column $\left(25 \mathrm{~cm} \times 4 \mathrm{~mm} \times 5 \mu \mathrm{m}\right.$ Lichrospher $\left.{ }^{\circledR} 100\right)$ coupled with a pre-column cartridge $\left(4 \mathrm{~mm}\right.$ LichroCART ${ }^{\circledR}$, Manu-CART $^{\circledR}$ '4'), a programmable solvent delivery system with a quaternary pump (model L-7100), a programmable multiwavelength UV spectrophotometer (model L-7400) and an interface (model D-7000), coupled with a software package for system control and data acquisition (model D-7000 Chromatographic Data Station Software), all from MERCK Instruments (San Jose, CA, USA).

\section{Methods}

Production of recombinant cutinase

This enzyme was produced elsewhere, as reported in detail by Calado et al. (2002) and Cunha et al. (2003), and kindly provided by those authors. In short, genetic engineering was integrated with production and purification of $F$. solani-pisi cutinase by a recombinant S. cerevisiae strain SU50; an aqueous two-phase system of PEG 3350, dipotassium phosphate and whole broth was then used for extraction of the extracellular cutinases expressed therein.

\section{Preparation of anhydrous butterfat}

Milkfat (from either bovine, ovine or caprine milks) was pre-treated by the procedure of Kalo et al. (1990), with slight modifications (Balcão \& Malcata, 1997, 1998a,b; 
Balcão et al., 1998a,b). Water was removed from butter in a separating funnel at $60{ }^{\circ} \mathrm{C}$, and fat was then filtered out using normal filter paper and dried in a vacuum of c. 800 mbar for $1 \mathrm{~h}$ in a boiling water bath. Anhydrous nitrogen was bubbled in the melted butterfat for c. 5 min (to help in removing residual oxygen and water); the dried fat was poured into $500-\mathrm{mL}$ Schott flasks, and stored under nitrogen at $-30{ }^{\circ} \mathrm{C}$ until experimental use.

\section{Performance of hydrolysis reactions}

All hydrolysis reactions involving butterfat were carried out at $40{ }^{\circ} \mathrm{C}$, using the experimental setup described above. For each reaction involving a particular milkfat and a given lipase, $130 \mathrm{~mL}$ of anhydrous butterfat was poured into the jacketed, round bottom flask, and thermal equilibration of the mixture $\left(\right.$ at $\left.40{ }^{\circ} \mathrm{C}\right)$ was then allowed to proceed for $c .10 \mathrm{~min}$. A $500-\mu \mathrm{L}$ sample was withdrawn and poured into a vial containing $2.25 \mathrm{~mL}$ of an internal standard solution $\left[1.0 \mathrm{~g} \mathrm{~L}^{-1}\right.$ of both margaric and non-anoic acids, in 1:1 (v/v) methanolchloroform containing $0.05 \%$ butylated hydroxyanisole] and $2 \mathrm{~g}$ of sodium sulphate. Crude lipase powder $(750 \mathrm{mg}$ ) was dissolved in $15 \mathrm{~mL}$ of Tris- $\mathrm{HCl}(\mathrm{pH} 7.0)$, and added to the flask. The reaction was allowed to proceed for $5 \mathrm{~h}$, with the medium being continuously agitated via magnetic stirring at 750 r.p.m. Aliquots were withdrawn at regular time intervals, poured directly into vials containing a known amount of the internal standard solution, and assayed for free fatty acids.

\section{Assay for free fatty acids}

Free fatty acids in plain butterfat and in the reaction mixture were analysed by HPLC, according to the procedures by Garcia et al. (1990) and Malcata (1991), with modifications (Sousa et al., 1996; Balcão \& Malcata, 1997, 1998a,b; Balcão et al., 1998a,b). For calibration, stock solutions of twelve different free fatty acid standards, viz. C4:0 (butyric acid), C6:0 (caproic acid), C8:0 (caprylic acid), C10:0 (capric acid), C12:0 (lauric acid), C14:0 (myristic acid), C16:0 (palmitic acid), C18:0 (stearic acid), C18:1 (oleic acid), C18:2 $\omega 6$ (linoleic acid), C18:3 $\omega 6$ ( $\gamma$-linolenic acid) and $\mathrm{C} 20: 0$ (arachidic acid) were obtained by weighing given amounts of the corresponding fatty acid standards and dissolving them in a $1: 1(\mathrm{v} / \mathrm{v})$ methanol/chloroform mixture, so as to obtain a final (known) concentration of c. $0.2 \mathrm{~mol} \mathrm{~L}^{-1}$ for each free fatty acid standard. Aliquots $(100 \mu \mathrm{L})$ of all stock solutions of fatty acid standards were added to a 1:1 (v/v) methanol/chloroform mixture, so as to obtain a total sample volume of $6.0 \mathrm{~mL}$. A volume of $4.5-\mathrm{mL}$ solution of internal standards containing $0.00316 \mathrm{~mol} \mathrm{~L}^{-1}$ of $\mathrm{C} 9: 0$ (non-anoic acid) and $0.00185 \mathrm{~mol} \mathrm{~L}^{-1}$ of $\mathrm{C} 17: 0$ (margaric acid) in a $1: 1(\mathrm{v} / \mathrm{v})$ methanol/chloroform mixture prepared according to a similar procedure [and further stabilised with $0.05 \%$ (v/w) butylated hydroxyanisole] was then added, so as to obtain a final $4: 3(\mathrm{v} / \mathrm{v})$ ratio of sample to internal standard solution. This procedure was independently carried out for other aliquots of the fatty acid standard stock solutions, viz. 200, 300, 400 and $500 \mu \mathrm{L}$. Aliquots $(100 \mu \mathrm{L})$ of each resulting solution were withdrawn and added to $4.0 \mathrm{~mL}$ of a $1 \mathrm{~g} \mathrm{~L}^{-1}$ solution of $p$-bromophenacylbromide in acetonitrile. To the resulting solution, $80 \mu \mathrm{L}$ of a $5 \mathrm{~g} \mathrm{~L}^{-1}$ solution of 18-crown-6-ether in acetonitrile was added, and this procedure was followed by addition of $0.2 \mathrm{~g}$ of potassium carbonate. After thorough mixing, this biphasic mixture was incubated at $75-80{ }^{\circ} \mathrm{C}$ for $30 \mathrm{~min}$ (in order to promote derivatisation), allowed to cool to near room temperature, added with $40 \mu \mathrm{L}$ of a $40 \mathrm{~g} \mathrm{~L}^{-1}$ solution of formic acid in acetonitrile (so as to quench derivatisation), and finally incubated at $75-80{ }^{\circ} \mathrm{C}$ for an additional $5 \mathrm{~min}$. Following refrigeration for at least $1 \mathrm{~h}$ (at $c .4{ }^{\circ} \mathrm{C}$ ), samples were cold-filtered through $0.45 \mu \mathrm{m}$ nylon membrane filters.
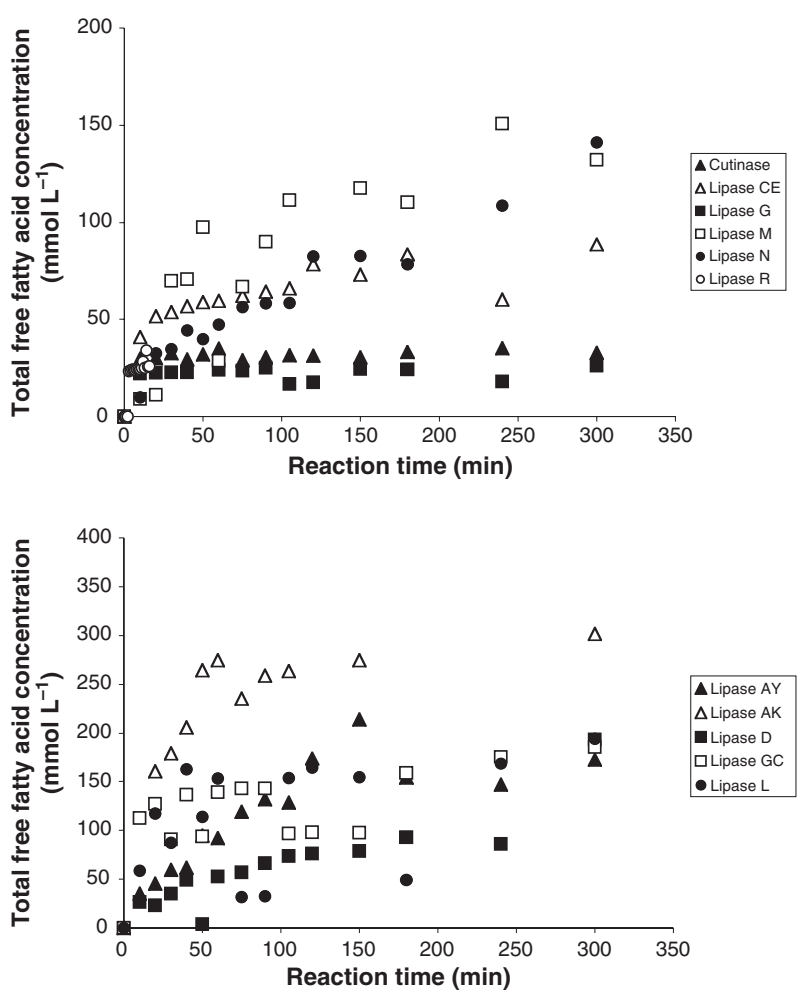

Figure 1 Changes with time in levels of total free fatty acid concentration in bovine milkfat, undergoing enzyme-mediated hydrolysis via recombinant cutinase from Fusarium solani pisii, and lipases from Candida cylindracea (AY), Pseudomonas fluorescens (AK), Humicola lanuginosa (CE), Rhizopus delemar (D), Penicillium camembertii (G), Geotrichum candidum (GC), Candida lipolytica (L), Mucor circinelloides (M), Rhizopus niveus (N) and Penicillium roquefortii (R). 

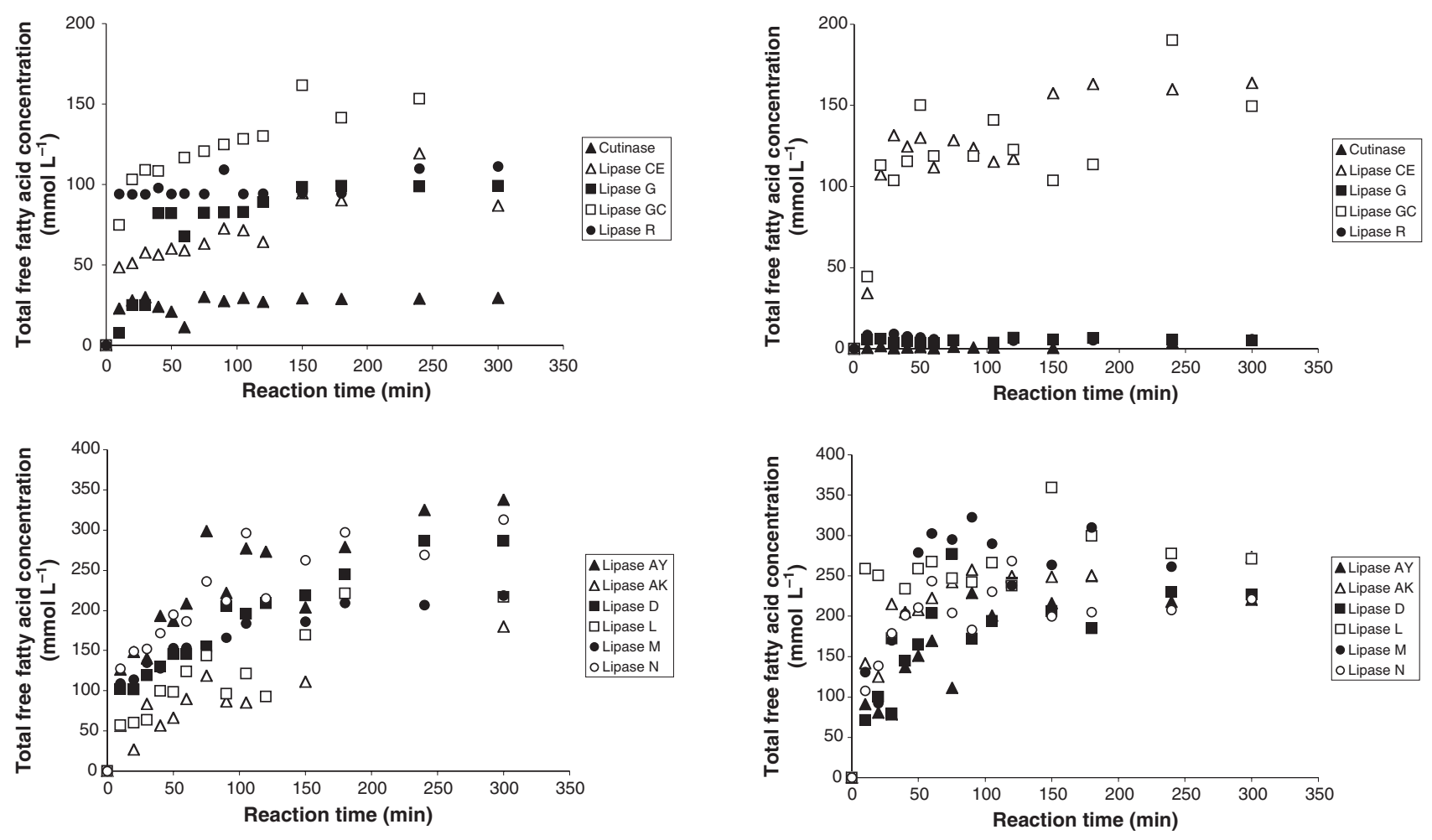

Figure 2 Changes with time in levels of total free fatty acid concentration in ovine milkfat, undergoing enzyme-mediated hydrolysis via recombinant cutinase from Fusarium solani pisii, and lipases from Candida cylindracea (AY), Pseudomonas fluorescens (AK), Humicola lanuginosa (CE), Rhizopus delemar (D), Penicillium camembertii (G), Geotrichum candidum (GC), Candida lipolytica $(\mathrm{L})$, Mucor circinelloides $(\mathrm{M})$, Rhizopus niveus $(\mathrm{N})$ and Penicillium roquefortii $(\mathrm{R})$.

For actual experiments, samples of LMF (withdrawn at pre-determined time intervals) were put in vials containing $2.25 \mathrm{~mL}$ of the internal standard solution and c. $2 \mathrm{~g}$ of anhydrous sodium sulphate; a volume of $500 \mu \mathrm{L}$ of this solution was withdrawn and poured into another vial containing $4 \mathrm{~mL}$ of $p$-bromophenacylbromide. After this point, the derivatisation procedure was the same as for calibration.

In either situation, aliquots of $20 \mu \mathrm{L}$ of the filtered samples were injected into the HPLC system described above; separation was effected at $33{ }^{\circ} \mathrm{C}$ using a mobile phase of water, methanol and acetonitrile under a complex gradient system - described elsewhere to some length by Balcão \& Malcata (1998a); the flow rate of eluant was $1 \mathrm{~mL} \mathrm{~min}{ }^{-1}$, and absorbance of the eluate was read at $254 \mathrm{~nm}$. These determinations were carried out in duplicate.

\section{Results and discussion}

The evolution with time of the total concentration of free fatty acids in hydrolysed bovine, ovine and caprine

Figure 3 Changes with time in levels of total free fatty acid concentration in caprine milkfat, undergoing enzyme-mediated hydrolysis via recombinant cutinase from Fusarium solani pisii, and lipases from Candida cylindracea (AY), Pseudomonas fluorescens (AK), Humicola lanuginosa (CE), Rhizopus delemar (D), Penicillium camembertii (G), Geotrichum candidum (GC), Candida lipolytica (L), Mucor circinelloides (M), Rhizopus niveus (N) and Penicillium roquefortii (R).

milkfats, incubated with each of the eleven microbial enzymes tested, is depicted in Figs 1-3. It is apparent that hydrolysis proceeded for $1-2 \mathrm{~h}$, and then essentially halted - most likely due to product inhibition and/or (reversible) enzyme inactivation, because of a progressively lower $\mathrm{pH}$ of the reaction media (Balcão et al., 1998c).

The mole percent of each individual fatty acid, from C4:0 to C18:3, relative to the total amount of fatty acids released by 5 h, is represented in Fig. 4 for the cutinase and all lipases experimented with. For most enzymes tested and with bovine and ovine substrates, the fatty acids released to a greater extent were $\mathrm{C} 16: 0$ and $\mathrm{C} 18: 0$, followed by $\mathrm{C} 12: 0$ and $\mathrm{C} 14: 0$. In the case of caprine milkfat, the fatty acid that underwent the highest extent of release was C16:0, while C18:0 was released at levels comparable to $\mathrm{C} 10: 0, \mathrm{C} 12: 0$ and $\mathrm{C} 14: 0$. Recall that 16and 18-carbon fatty acid residues are the predominant ones in milkfats, so our results are expected based on substrate competition for the active site. The degree of hydrolysis, and the profiles of fatty acids released are 

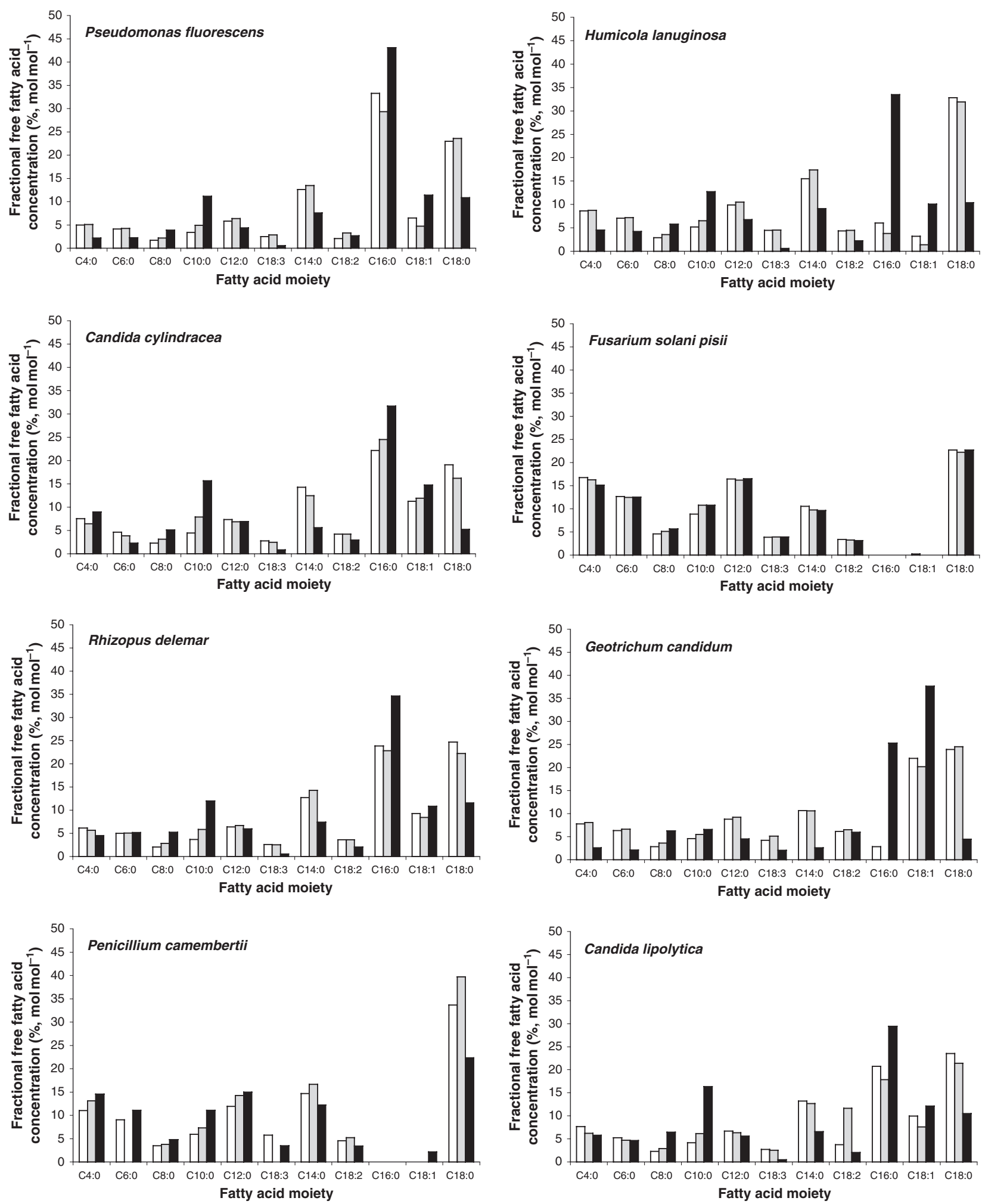

Figure 4 Fractional concentration of each free fatty acid normalised by the total free fatty acid concentration, by 300 min of hydrolysis, in bovine $(\square)$, ovine $(\square)$ and caprine ( $\square$ ) milkfats, mediated by the recombinant cutinase and lipases from various sources. 

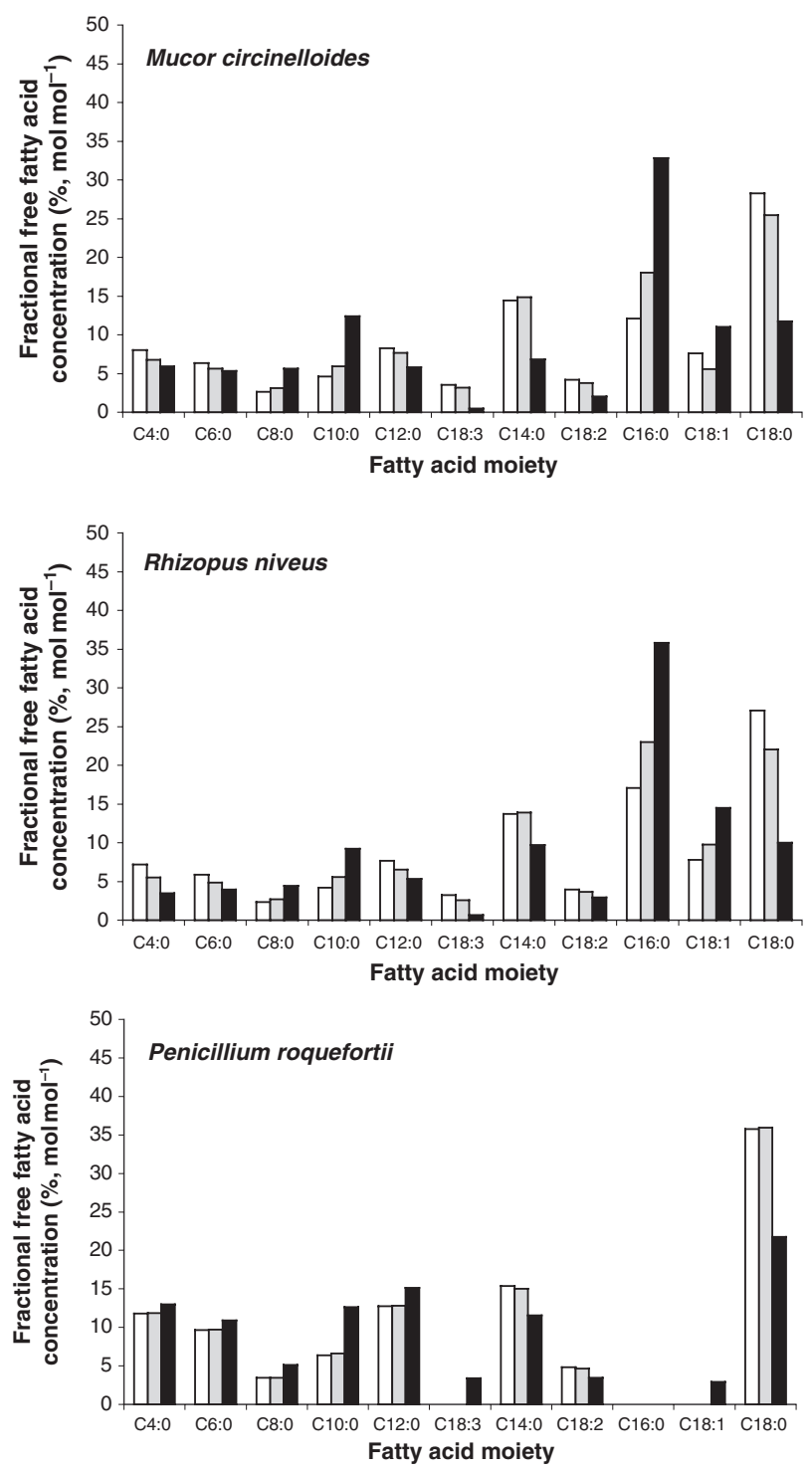

Figure 4 (Continued) also in agreement with previous reports on the experimental manufacture of EMCs. Moskowitz \& Noelck (1987) studied Swiss and Cheddar types of EMC, and observed that palmitic acid attained the highest concentration. Kilcawley et al. (2001) reported a similar conclusion, based on a survey of fifteen commercial Cheddar-based EMC products. The results obtained pertaining to $P$. fluorescens lipase can also be compared with those by Marangoni (1994), referring to hydrolysis of butteroil brought about by a similar lipase: the predominant fatty acid released was, once again, palmitic acid, followed by the C18 family, and then by butyric acid.

Quite distinctive results were produced by cutinase, in particular when acting upon bovine and ovine milkfats. In these cases, the proportions of short-to-medium chain free fatty acids were significantly higher, as shown in Table $1-$ e.g. free butyric acid levels were $16-17 \%$, and free caproic acid levels were 13-14\%, irrespective of substrate; furthermore, there was essentially no net

Table 1 Proportions of Short(C4-C8) : Medium (C10-C14) : Long (C16-C18) chain fatty acid moieties in lipolysed milkfats (LMF) from various origins, by $300 \mathrm{~min}$ of hydrolysis

\begin{tabular}{llll}
\hline & \multicolumn{3}{l}{ S:M:L proportions in LMFs } \\
\cline { 2 - 4 } Cutinase Lipase source & $\begin{array}{l}\text { Bovine } \\
\text { milkfat }\end{array}$ & $\begin{array}{l}\text { Ovine } \\
\text { milkfat }\end{array}$ & $\begin{array}{l}\text { Caprine } \\
\text { milkfat }\end{array}$ \\
\hline Candida cylindracea & $14: 26: 60$ & $14: 27: 59$ & $17: 28: 55$ \\
Pseudomonas fluorescens & $11: 22: 67$ & $11: 25: 64$ & $8: 23: 69$ \\
Fusarium solani pisii & $34: 36: 30$ & $34: 37: 29$ & $33: 37: 30$ \\
Humicola lanuginosa & $18: 31: 51$ & $20: 34: 46$ & $14: 29: 57$ \\
Rhizopus delemar & $13: 23: 64$ & $13: 27: 60$ & $15: 25: 60$ \\
Penicillium camembertii & $24: 32: 44$ & $17: 38: 45$ & $31: 38: 31$ \\
Geotrichum candidum & $17: 24: 59$ & $18: 26: 56$ & $11: 14: 75$ \\
Candida lipolytica & $15: 24: 61$ & $14: 25: 61$ & $17: 28: 55$ \\
Mucor circinelloides & $17: 27: 56$ & $16: 28: 56$ & $17: 25: 58$ \\
Rhizopus niveus & $15: 26: 59$ & $13: 26: 61$ & $12: 24: 64$ \\
Penicillium roquefortii & $25: 34: 41$ & $25: 34: 41$ & $29: 39: 32$ \\
\hline
\end{tabular}

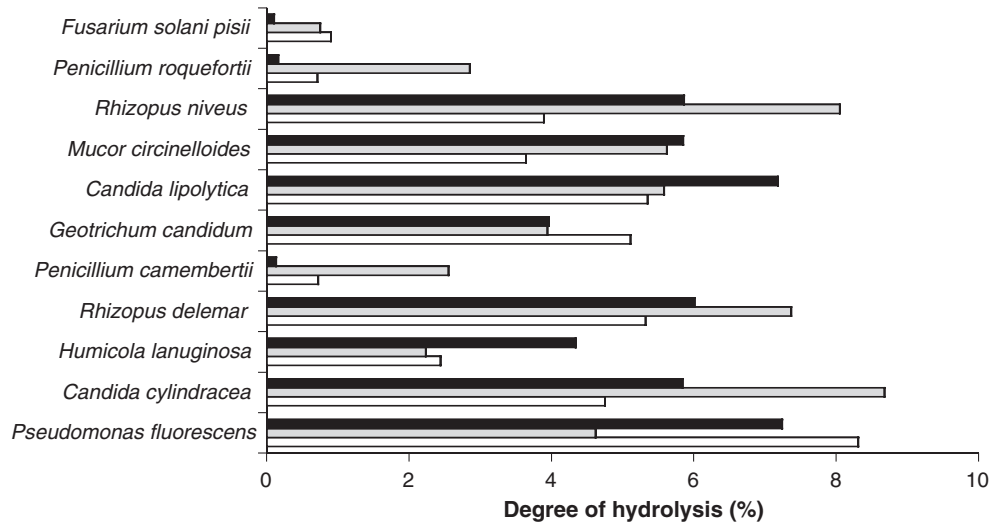

Figure 5 Net overall degree of hydrolysis, by $300 \mathrm{~min}$, in bovine ( $\square$ ), ovine ( $\square$ ) and caprine milkfats, mediated by the recombinant cutinase and lipases from various sources. 
release of $\mathrm{C} 16: 0$, which is in agreement with the specificity claimed for this enzyme (Carvalho et al., 1998). Also worthy of mention are the high amounts of C18:1, C18:2 and C18:3 released by the lipase from $G$. candidum; it is known (de Greyt \& Huyghebaert, 1995) that this enzyme possesses high specificity for long-chain fatty acid moieties containing a cis-double bond at the $n-9$ position. Therefore, the profile of free short-tomedium chain fatty acids apparently depends on the microbial source of lipase - a realisation that is consistent with claims by Ha \& Lindsay (1993).

Based on the average overall fatty acid composition of milkfat, as reported by Nawar (1985), Alonso et al. (1999) and Jensen (2002), the average molecular weight of the fatty acids esterified in bovine milkfat is $c$. $236.5 \mathrm{~g} \mathrm{~mol}^{-1}$, that of ovine milkfat is $c .220 .0 \mathrm{~g} \mathrm{~mol}^{-1}$ and that of caprine milkfat is $c .227 .2 \mathrm{~g} \mathrm{~mol}^{-1}$. Assuming that milkfat is composed only of triglyceride molecules, and considering that the density of milkfat at $40{ }^{\circ} \mathrm{C}$ is $0.905 \mathrm{~g} \mathrm{~mL}^{-1}$ (Kurtz, 1965), then the theoretical amount of fatty acids released from milkfat, in the case of complete hydrolysis, would lead to a total concentration of c. $3632 \mathrm{mmol} \mathrm{L}^{-1}$ for bovine milkfat, $3890 \mathrm{mmol} \mathrm{L}^{-1}$ for ovine milkfat and $3773 \mathrm{mmol} \mathrm{L}^{-1}$ for caprine milkfat. The combination of these values with the data depicted in Figs 1-3 enables one to estimate the fractional net hydrolysis by $5 \mathrm{~h}$ of reaction. These results are plotted in Fig. 5. From inspection of this figure, one concludes that net hydrolysis of milkfat has occurred in all cases to extents below $10 \%$. The highest net degrees of hydrolysis were achieved via the action of $C$. cylindracea lipase upon ovine milkfat $(8.7 \%), R$. niveus lipase upon ovine milkfat $(8.0 \%)$ and $P$. fluorescens lipase upon bovine milkfat $(8.3 \%)$. Also, high were the degrees of hydrolysis promoted by $R$. delemar lipase on ovine milkfat $(7.4 \%)$ and by C. lipolytica lipase on caprine milkfat $(7.2 \%)$. On the other hand, the recombinant cutinase produced the lowest degrees of hydrolysis, particularly when acting upon caprine milkfat $(0.1 \%)$.

Comparing the degrees of hydrolysis produced by each enzyme on the three distinct raw materials, one concludes that, in most cases, it was higher in the case of ovine or caprine milkfats. Overall, the levels of hydrolysis may be considered low, but they lie in the usual range observed in LMF or EMC products (de Greyt \& Huyghebaert, 1995).

In view of the above, one concludes that the milkfat systems utilised in this work are amenable to enzymatic modifications that parallel those carried out in the manufacture of LMF. Those modified substrates have indeed the potential to be used as ingredients for which advantage of their unique free fatty acid profile (both qualitative and quantitative) can be taken, so as to impart specific flavour notes to the final product. Sensory evaluation of the LMFs remains, nevertheless, to be carried out in complementary works.

\section{Acknowledgments}

Funding for authors M. A. Regado and B. M. Cristóvão was via Research Fellowships granted by FCT (Portugal). Funding for this research effort was via Project IMPROVEMENT: IMPROVement of Enzyme-Modified chEeses towards fuNcTionality, POCTI/1999/ AGR/36196 (Portugal).

\section{References}

Alonso, L., Fontecha, J., Lozada, L., Fraga, M. J. \& Juárez, M. (1999). Fatty acid composition of caprine milk: major, branchedchain, and trans fatty acids. Journal of Dairy Science, 82, 878-884.

Balcão, V. M. \& Malcata, F. X. (1997). Lipase-catalyzed modification of butterfat via acidolysis with oleic acid. Journal of Molecular Catalysis B: Enzymatic, 3, 161-169.

Balcão, V. M. \& Malcata, F. X. (1998a). Interesterification and acidolysis of butterfat with oleic acid by Mucor javanicus lipase: changes in the pool of fatty acid residues. Enzyme and Microbial Technology, 22, 511-519.

Balcão, V. M. \& Malcata, F. X. (1998b). On the performance of a hollow-fiber bioreactor for acidolysis catalyzed by immobilized lipase. Biotechnology and Bioengineering, 60, 114-123.

Balcão, V. M., Kemppinen, A., Malcata, F. X. \& Kalo, P. (1998a). Lipase-catalyzed acidolysis of butterfat with oleic acid: characterization of process and product. Enzyme and Microbial Technology, 23, 118-128.

Balcão, V. M., Kemppinen, A., Malcata, F. X. \& Kalo, P. (1998b). Modification of butterfat by selective hydrolysis and interesterification by lipase: process and product characterization. Journal of the American Oil Chemists' Society, 75, 1347-1358.

Balcão, V. M., Oliveira, T. A. \& Malcata, F. X. (1998c). Stability of a commercial lipase from Mucor javanicus: kinetic modelling of $\mathrm{pH}$ and temperature dependencies. Biocatalysis and Biotransformation, 16, 45-66.

Calado, C. R. C., Taipa, A. M., Cabral, J. M. S. \& Fonseca, L. P. (2002). Optimisation of culture conditions and characterisation of cutinase produced by recombinant Saccharomyces cerevisiae. Enzyme and Microbial Technology, 31, 161-170.

Carvalho, C. M. L., Aires-Barros, M. R. \& Cabral, J. M. S. (1998). Cutinase structure, function and biocatalytic applications. Electronic Journal of Biotechnology, 1, 160-173.

Cunha, M. T., Costa, M. J. L., Calado, C. R. C., Fonseca, L. P., AiresBarros, M. R. \& Cabral, J. M. S. (2003). Integration of production and aqueous two-phase systems extraction of extracellular Fusarium solani pisi cutinase fusion proteins. Journal of Biotechnology, 100, 55-64.

Garcia, H. S., Reyes, H. R., Malcata, F. X., Hill, C. G. \& Amundson, C. H. (1990). Determination of the major free fatty acids in milkfat using a 3-component mobile phase for HPLC analysis. Milchwissenschaft-Milk Science International, 45, 757-759.

de Greyt, W. \& Huyghebaert, A. (1995). Lipase-catalysed modification of milkfat. Lipid Technology, 7, 10-12.

Ha, J. K. \& Lindsay, R. C. (1993). Release of volatile branched-chain and other fatty acids from ruminant milkfats by various lipases. Journal of Dairy Science, 76, 677-690.

Jensen, R. G. (2002). The composition of bovine milk lipids. Journal of Dairy Science, 85, 295-350.

Kalo, P., Huotari, H. \& Antila, M. (1990). Pseudomonas fluorescens lipase-catalysed interesterification of butterfat in the absence of a solvent. Milchwissenschaft-Milk Science International, 45, 281-285. 
Kilcawley, K. N. (2001). The enzyme effect. Dairy Industries International, 66, 26-28.

Kilcawley, K. N., Wilkinson, M. G. \& Fox, P. F. (2001). A survey of lipolytic and glycolytic end-products in commercial Cheddar enzyme-modified cheese. Journal of Dairy Science, 84, 66-73.

Kurtz, F. E. (1965). The lipids of milk: composition and properties. In: Fundamentals of Dairy Chemistry (edited by B. H. Webb \& A. H. Johnson). Pp. 161.Westport, CT: AVI Publishing Company.

Lai, D. T., Mackenzie, A. D., O'Connor, C. J. \& Turner, K. W. (1997). Hydrolysis characteristics of bovine milkfat and monoacid triglycerides mediated by pregastric lipase from goats and kids. Journal of Dairy Science, 80, 2249-2257.

Malcata, F. X. (1991). Hydrolysis of butterfat by immobilized lipase using three-phase membrane reactors. PhD. Thesis, University of Wisconsin, Madison.
Marangoni, A. G. (1994). Candida and Pseudomonas lipase-catalyzed hydrolysis of butteroil in the absence of organic solvents. Journal of Food Science, 59, 1096-1099.

Moskowitz, G. J. \& Noelck, S. S. (1987). Enzyme-modified cheese technology. Journal of Dairy Science, 70, 1761-1769.

Nawar, W. W. (1985). Lipids. In: Food Chemistry (edited by O. R. Fennema). P. 139. New York, NY: Marcel Dekker.

Sousa, M. J., Balcão, V. M. \& Malcata, F. X. (1996). Evolution of free fatty acid profile during ripening in cheeses manufactured from bovine, ovine, and caprine milks with extracts of Cynara cardunculus as coagulant. Zeitschrift fur Lebensmittel-Untersuchung und-Forschung A-Food Research and Technology, 205, 104-107.

Talbott, L. L. \& McCord, C. (1981). The Use of Enzyme-Modified Cheeses for Flavoring Processed Cheese Products. Madison, WI: Marschall International Cheese Conference, September 15-18. 